\title{
REPRODUCTIVE IMPACTS OF TRIBUTYLTIN (TBT) AND TRIPHENYLTIN (TPT) IN THE HERMAPHRODITIC FRESHWATER GASTROPOD LYMNAEA STAGNALIS
}

\author{
Arnaud Giusti, $\dagger \ddagger$ Alpar Barsi, $\ddagger$ MaËl Dugué, $\ddagger$ Marc Collinet, $\ddagger$ Jean-Pierre Thomé, $†$ Célia Joaquim-Justo, $\dagger$ \\ Benoit Roig, $\S \|$ LaURent Lagadic, $\ddagger$ and VIrgINIE Ducrot* $¥$ \\ $\dagger$ Laboratory of Animal Ecology and Ecotoxicology, Center of Analytical Research and Technology, Liège University, Liège, Belgium \\ ‡INRA, Joined Research Unit 985 Ecology and Ecosystem Health, Rennes, France \\ $\S$ EHESP, Rennes, France \\ ||INSERM U1085-IRSET, LERES, France
}

(Submitted 6 November 2012; Returned for Revision 18 December 2012; Accepted 11 February 2013)

\begin{abstract}
Tributyltin (TBT) and triphenyltin (TPT) are emblematic endocrine disruptors, which have been mostly studied in gonochoric prosobranchs. Although both compounds can simultaneously occur in the environment, they have mainly been tested separately for their effects on snail reproduction. Because large discrepancies in experimental conditions occurred in these tests, the present study aimed to compare the relative toxicity of TBT and TPT under similar laboratory conditions in the range of $0 \mathrm{ng} \mathrm{Sn} / \mathrm{L}$ to $600 \mathrm{ng} \mathrm{Sn} / \mathrm{L}$. Tests were performed on the simultaneous hermaphrodite Lymnaea stagnalis, a freshwater snail in which effects of TPT were unknown. Survival, shell length, and reproduction were monitored in a 21-d semistatic test. Frequency of abnormal eggs was assessed as an additional endpoint. Triphenyltin hampered survival while TBT did not. Major effects on shell solidity and reproduction were observed for both compounds, reproductive outputs being more severely hampered by TBT than by TPT. Considering the frequency of abnormal eggs allowed increasing test sensitivity, because snail responses to TBT could be detected at concentrations as low as $19 \mathrm{ng} \mathrm{Sn} / \mathrm{L}$. However, the putative mode of action of the 2 compounds could not be deduced from the structure of the molecules or from the response of apical endpoints. Sensitivity of $L$. stagnalis to TBT and TPT was compared with the sensitivity of prosobranch mollusks with different habitats and different reproductive strategies. Environ Toxicol Chem 2013;32:1552-1560. (C) 2013 SETAC
\end{abstract}

Keywords: Reproductive toxicity Endocrine disruptors Mollusk toxicology Organotin Toxicity mechanisms

\section{INTRODUCTION}

Organotins have been used for more than $50 \mathrm{yr}$, mainly as pesticides, antifungal agents and, in the case of the widely used tributyltin (TBT) and triphenyltin (TPT), as the active biocides of antifouling paints [1]. Their use in antifouling paints was prohibited in 2008 [2], but residues can still be found both in marine environments and in freshwater ecosystems at concentrations up to, for example, 7.1 $\mu \mathrm{g}$ TBT/L [3]. Therefore, the assessment of toxic effects of these compounds to aquatic, freshwater wildlife is still relevant. To date, TBT and TPT have mostly been investigated separately as single compounds. These studies have pointed out some similarities between TPT and TBT regarding their physicochemical properties and biological effects. Indeed, these molecules have a closely related structure: a tetravalent tin core with either 3 butyls (TBT) or 3 phenyls (TPT). These compounds are fairly persistent in the environment, being retained in sediments [4-6]. Furthermore, they penetrate biological systems and can be stored at high concentrations in lipid-rich tissues of aquatic organisms; for example, TBT levels up to $233 \mathrm{ng} / \mathrm{g}$ have been recorded in retail mollusk products [7]. Both TBT and TPT accumulate preferentially in the hepatopancreas and kidneys and at lower levels in the heart and brain [8-10]. Consequently, both TBT and TPT can induce adverse effects on wildlife, which have been studied mainly in marine mollusks.

As early as 1975, adverse impacts of TBT-shell calcification in adults leading to stunted growth-were observed in the oyster

* Address correspondence to virginie.ducrot@ rennes.inra.fr.

Published online 28 February 2013 in Wiley Online Library (wileyonlinelibrary.com).

DOI: $10.1002 /$ etc. 2200
Crassostrea gigas [11]. At low concentrations (nanograms per liter), TBT was shown to induce the imposition of male sex organs in female prosobranchs [12]. This phenomenon, named imposex, has now been reported to occur in more than 200 mesogastropod and neogastropod marine and freshwater species [13]. At highly contaminated sites, females can be sterilized or even killed, which may affect population dynamics [14]. In addition, TPT was shown to induce reproductive failure through imposex in different gastropod species [15-17]. A number of studies reported other types of reproductive alterations in freshwater species due to exposure to organotins [18-24]. For instance, exposure of Lymnaea stagnalis to TBT at $1 \mu \mathrm{g} \mathrm{Sn} / \mathrm{L}$ was shown to induce abnormal development of embryos (absence of shell), and a decrease in egg hatchability; exposure to $10 \mu \mathrm{g} \mathrm{Sn} / \mathrm{L}$ led to a complete hatching failure [19].

Organotins generally occur in the environment as mixtures of TBT and TPT and their derivatives (i.e., dibutyltin [DBT], monobutyltin [MBT], diphenyltin [DPT], and monophenyltin [MPT]) [25,26]. Therefore, a growing number of studies are devoted to the study of the relative toxicity of these compounds, which constitutes the first step toward the study of mixture toxicity. Comparisons of bioaccumulation and biological responses to TBT and TPT have already been done in several gastropod species such as the muricids Thais clavigera and Thais bronni [27], as well as Bolinus brandaris and Hexaplex trunculus [28]. These studies allow a straightforward comparison of TBT and TPT effects under similar test designs and experimental conditions and using similar test endpoints. This ensures both quantitative and qualitative reliability of effect comparisons through the avoidance of experimental confounding factors, which often occur when data from different studies are compared. To date, these comparative studies have dealt 
only with gonochoric species, in which toxic effects can be assessed through direct monitoring of the morphological changes in the sexual apparatus. Furthermore, impacts on endocrinology and especially on sexual steroids are more easily understood in species that exhibit separated genders, in which the male and female hormonal reproductive pathways can be distinguished.

Effects on the reproductive pathways and performances in hermaphroditic species are more subtle. Probably due to the complex sexual apparatus and the variety of reproduction strategies in simultaneous hermaphrodite gastropods (e.g., selfing vs outcrossing) [29], the effects of organotins in these animals have not yet been extensively investigated [20]. In particular, it is important to investigate suitable endpoints that will allow the highlighting of reproductive effects in species in which sex differentiation cannot be used as an effect criterion. To date, most studies have been conducted using the great pond snail L. stagnalis. This holarctic freshwater snail lives in ponds and lakes. It is a simultaneous hermaphrodite, which can outcross and self-fertilize [30]. It has been identified as one of the most relevant mollusk species for assessing reprotoxic effects of chemicals [20,29,31-33]. Because its neurohormonal control of reproduction is reasonably well understood compared with other mollusk species [32-35], and also because it has been shown to be sensitive to endocrine disruptors [19,21,24,31,35], standard Organization for Economic Cooperation and Development (OECD) test guidelines for apical reprotoxicity tests (both partial and full life-cycle tests) with L. stagnalis are currently under development.

In the present study, we aimed to investigate the reproductive effects of the emblematic organotin compounds TBT and TPT, known as endocrine disruptors in some mollusk species, in the hermaphroditic freshwater snail L. stagnalis. The effects of TBT and TPT were studied comparatively under the same controlled laboratory conditions. Reproductive effects were assessed through a set of complementary apical endpoints (i.e., number of egg clutches, number of eggs, and frequency and type of abnormal eggs). Adult survival and growth also were monitored. Effects of TBT and TPT were compared both qualitatively and quantitatively. The influence of the structure of the molecules on the biological responses and possible corresponding modes of toxic action were discussed. Moreover, biological responses of this hermaphroditic snail to TBT and TPT were compared with available data in other mollusk species.

\section{MATERIALS AND METHODS}

\section{Test organisms}

Lymnaea stagnalis (Linnaeus, 1758; Mollusca, Gastropoda, Panpulmonata, Heterobranchia) were reared at the Experimental Unit of Aquatic Ecology and Ecotoxicology (National Institute for Agricultural Research, Rennes, France) under laboratory conditions as previously described [30]. The culture medium consisted of dechlorinated, charcoal-filtered tap water with the following physicochemical characteristics: $\mathrm{pH} 7.7 \pm 0.2$, conductivity $623 \pm 60 \mu \mathrm{S} / \mathrm{cm}$, dissolved oxygen $7.3 \pm 2 \mathrm{mg} /$ $\mathrm{L}$, and water hardness $254 \pm 7 \mathrm{mg} \quad \mathrm{CaCO}_{3} / \mathrm{L}$. Rearing conditions were as follows: temperature $20 \pm 1{ }^{\circ} \mathrm{C}$, photoperiod 14:10-h light:dark, and light intensity $155 \pm 35$ lux. Snails (RENILYS® strain) were fed 3 times per week with organic lettuce. Young adult snails-in which reproduction endpoints are more sensitive to chemicals, including some endocrinedisrupting chemicals, than in fully grown snails [35]-were used. Snails of homogenous size $(22.5 \pm 2.5 \mathrm{~mm})$ and age
( $4 \pm 0.5$ months) were sampled from the culture and acclimatized to test conditions (i.e., similar to culture conditions, but with a higher food quantity provided per individual) during the $48 \mathrm{~h}$ prior to chemical exposure.

\section{Tested chemicals and concentrations}

Tributyltin hydride (Chemical Abstract Service [CAS] number 688-73-3) and triphenyltin chloride (CAS number 639-58-7) were dissolved in analytical grade acetone $(99.9 \%$ purity) to prepare stock solutions $(10 \mu \mathrm{g} / \mu \mathrm{L})$. Final solvent concentration $(100 \mu \mathrm{L} / \mathrm{L})$ was homogenous among treatments, as recommended by the OECD [36] (except for the water controls). Exposure media consisted of culture water contaminated with stock solutions. Organotin concentrations were chosen based on literature data in gastropods [15,18,22,37] and L. stagnalis [19,21]. Range-finding tests in L. stagnalis were also performed under similar tests conditions [38,39]. Based on this information, the chosen nominal concentrations were $45 \mathrm{ng} \mathrm{Sn} / \mathrm{L}$, $100 \mathrm{ng} \mathrm{Sn} / \mathrm{L}, 220 \mathrm{ng} \mathrm{Sn} / \mathrm{L}, 480 \mathrm{ng} \mathrm{Sn} / \mathrm{L}$, and $1065 \mathrm{ng} \mathrm{Sn} / \mathrm{L}$ for TBT, and $100 \mathrm{ng} \mathrm{Sn/L,} 215$ ng Sn/L, 755 ng Sn/L, 1000 ng Sn/L, and $2626 \mathrm{ng} \mathrm{Sn/L}$ for TPT. To facilitate the quantitative comparison of TBT versus TPT effects, all concentrations were expressed in tin equivalent; concentrations could thus be compared on a molar basis.

\section{Test design and biological endpoints}

Six replicates (each with 5 snails in 1-L glass beakers) per tested concentration, water control, and solvent control were randomly distributed in the exposure room. Snails were exposed to toxicant for only $21 \mathrm{~d}$ because this duration was sufficient to provide evidence of effects and assess various effective concentration (ECx) values for the compounds tested in the proposed experimental conditions (as determined in preexperiments). Test water was renewed with freshly contaminated medium to maintain exposure concentrations and adequate physicochemical properties of test water. Renewal rates resulted from a compromise between maintaining exposure concentration and avoiding too much stress to the snails. Independent studies showed that in our test conditions, TBT water concentration dropped rapidly ( $92 \%$ losses in $72 \mathrm{~h}$ ), so that the TBT test medium was renewed every other day. The TPT was more stable $(62 \%$ losses in $72 \mathrm{~h})$, and thus the TPT test medium was renewed every $3 \mathrm{~d}$. Tests were conducted at $20.5 \pm 0.6{ }^{\circ} \mathrm{C}$ and in a $14: 10$-h light:dark photoperiod as previously described [35]. Snails were fed daily ad libitum with organic lettuce rinsed with culture water, which is an adequate food source to support adult snail growth and reproduction [40].

Dead snails were counted and removed daily. Individual shell length was measured using a digital calliper at days 0 and 21 to assess a possible impact on growth. Effects on reproduction were estimated by monitoring the cumulated number of egg clutches per snail and the cumulated number of eggs per snail. Every day, clutches were counted, removed using a sharp-edged spoon, and photographed. The number and quality of the eggs were determined by observation of the photographs. Egg quality was assessed by determining the frequency of 4 types of abnormalities (Figure 1A-E): polyembryonic egg (the presence of several embryos per egg; unfertilized egg (the absence of embryo in the egg, which only consists of the eggshell and albumen; atrophied albumen (damaged eggshell containing an abnormally low albumen quantity); and single embryo (presence of a nondeveloping embryo, without an eggshell and without albumen). Polyembryonic and unfertilized eggs have been described before [41-43], and polyembryony has been shown to be a 


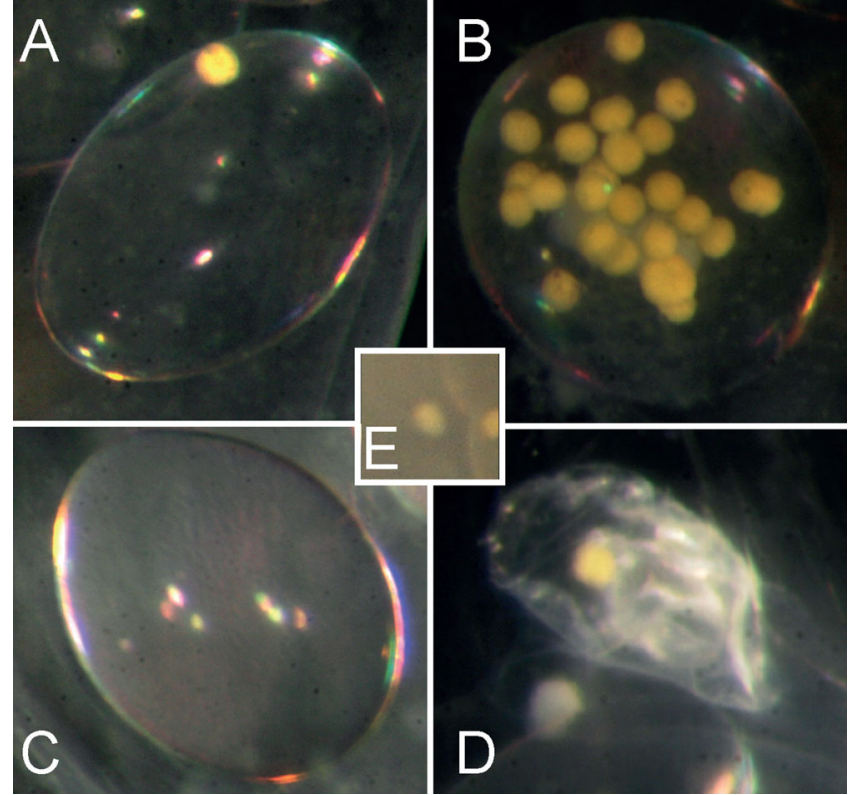

Figure 1. Different egg abnormalities observed in Lymnaea stagnalis. (A) normal egg; (B) polyembryonic egg; (C) unfertilized egg; (D) egg with atrophied albumen; and (E) single embryonic cell. [Color figure can be seen in the online version of this article, available at wileyonlinelibrary.com]

sensitive endpoint [41]. The 2 other abnormalities are described for the first time in L. stagnalis.

\section{Chemical analysis}

Water was sampled in controls and every tested concentration at the beginning, middle, and end of the tests. Water was collected both 15 min after stirring stock solutions in clean water (i.e., new exposure water) and just before water renewal (i.e., old exposure water) to allow calculation of time-weighted average exposure concentrations. For each concentration and sampling date, 3 samples of $1 \mathrm{~L}$ were collected, which consisted of a mixture of $165 \mathrm{~mL}$ of water extracted from each exposure replicate. In the TBT experiment, mucus that had accumulated on the walls of the test beakers was also collected for chemical analysis. Samples were frozen until analysis of their MBT, DBT, and TBT and TPT content. Analyses were performed by coupled capillary gas chromatography/mass spectrometry, with a limit of quantification of $10 \mathrm{ng} \mathrm{Sn/L} \mathrm{equivalent} \mathrm{[44].}$

\section{Data analysis}

Actual exposure concentrations were calculated as the timeweighted average of measured values over the test, using the formula proposed in Belgers et al. [45]. Biological data were analyzed with standard statistical analysis procedures, as described by the OECD [46], using Sigma-Stat (Jandel Scientific) and GraphPad Prism 5.0 software. Analyses of survival and reproduction data were based on observations for the 6 replicates, and analysis of growth data was based on individual length measurements. Analysis of abnormality frequency was based on the total number of clutches collected during the experiment. Statistical differences between water and solvent controls were determined using $t$ tests or Wilcoxon tests. When a significant difference with water control was shown for one of the compounds, solvent controls were used as the reference in subsequent statistical studies for both compounds. Indeed, using the same type of controls for the calculation of ECx values allows one to avoid confounding effects of the solvent. In other cases, water and solvent controls were combined. Differences among treatments in survival, shell length, and cumulated number of clutches and eggs per individual were tested using Kruskal-Wallis tests, with Dunn's post hoc tests for survival and size and Dunnet's post hoc test for reproductive endpoints. Differences in the frequency of abnormal eggs were assessed using Mann-Whitney tests. All tests were performed with $\alpha=0.05$. In case of significant effects of TBT or TPT, lethal concentrations (LCx) or ECx were calculated using a logistic regression model [47]. The 95\% confidence intervals (CI) were simulated based on weighted residues to account for differences in variance across treatments and using 5000 bootstrap simulations. The Microsoft Excel macro REGTOX_EV7.0.6 xls was used for this purpose [48].

\section{RESULTS}

\section{Actual exposure conditions}

The chemical preparation and contamination method resulted in exposure concentrations corresponding to $62.7 \pm 14.2 \%$ and $87.5 \pm 17.6 \%$ of the nominal TBT and TPT concentrations, respectively, at day 0 . Water concentrations dropped rapidly and with different kinetics for TBT and TPT. Before water renewal, exposure concentrations had dropped to $35.7 \pm 4 \%$ and $18.1 \pm 3 \%$ of the nominal TBT and TPT concentrations, respectively. This resulted in time-weighted average concentration ranges of $19 \mathrm{ng} \mathrm{Sn} / \mathrm{L}, 43 \mathrm{ng} \mathrm{Sn} / \mathrm{L}, 94 \mathrm{ng} \mathrm{Sn} / \mathrm{L}, 197 \mathrm{ng} \mathrm{Sn} / \mathrm{L}$, and $473 \mathrm{ng} \mathrm{Sn} / \mathrm{L}$ for TBT, and $45 \mathrm{ng} \mathrm{Sn} / \mathrm{L}, 74 \mathrm{ng} \mathrm{Sn} / \mathrm{L}, 187 \mathrm{ng} \mathrm{Sn} / \mathrm{L}$, $265 \mathrm{ng} \mathrm{Sn/L}$, and $590 \mathrm{ng} \mathrm{Sn/L}$ for TPT. High TBT concentrations were also found in the mucus sampled after $21 \mathrm{~d}$ (e.g., $1563 \pm 638 \mathrm{ng} \mathrm{Sn} / \mathrm{L}$ at the highest tested concentration). Both MBT and DBT were found in water, due to the degradation of TBT. Concentrations of MBT and DBT were not included in the calculation of TBT time-weighted average concentrations because their concentrations were generally lower than the quantification limit, so they could be ignored.

\section{Survival}

Survival was $100 \%$ in water controls from both tests and $93 \%$ and $88 \%$ in the solvent controls from TBT and TPT tests, respectively. No significant mortality was recorded following exposure to TBT over the test duration. Exposure to the highest tested concentration of TPT (590 ng Sn/L) led to $100 \%$ mortality after $3 \mathrm{~d}$ of exposure ( $p<0.05$, Dunn's post hoc test), while lower concentrations did not significantly affect survival. The corresponding median lethal concentration (LC50) at $21 \mathrm{~d}$ was estimated to be $436.1 \mathrm{ng} \mathrm{Sn} / \mathrm{L}$ (CI: 308.1-433.6 ng Sn/L).

\section{Shell size and integrity}

Shell length at $21 \mathrm{~d}$ was significantly reduced in snails exposed to TBT concentrations exceeding $94 \mathrm{ng} \mathrm{Sn} / \mathrm{L}$ (Figure 2A). A nonsignificant decrease was also observed in snails exposed to $43 \mathrm{ng} \mathrm{Sn} / \mathrm{L}$. A careful inspection of snails showed that the apex of the shells was broken in some or all of the exposed individuals, leading to reduced shell length. Snails exposed to $0 \mathrm{ng} \mathrm{Sn} / \mathrm{L}$ and $19 \mathrm{ng} \mathrm{Sn/L} \mathrm{generally} \mathrm{did} \mathrm{not} \mathrm{suffer}$ such injury. This finding suggests that broken shells were not experimental artifacts but a consequence of exposure to TBT. Indeed, the frequency of harmed shells increased linearly with TBT concentration $\left(r^{2}=0.94\right)$ and reached $100 \%$ at the highest tested concentration of $473 \mathrm{ng} \mathrm{Sn/L} \mathrm{(Figure} \mathrm{3A).} \mathrm{Therefore,} \mathrm{the}$ reduction in shell length provides evidence for the effects of TBT on shell solidity. Analysis of size data only in snails that did not suffer shell injury highlighted a significant reduction in growth 
A

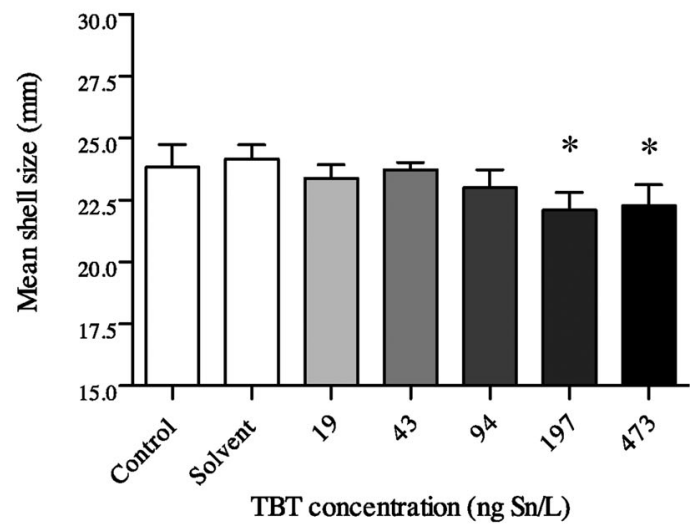

B

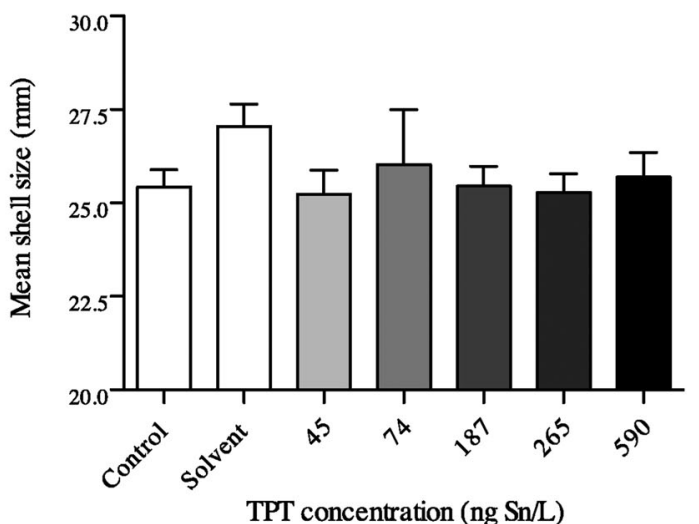

Figure 2. Mean shell size after a 21-d exposure to (A) tributyltin (TBT) or (B) triphenyltin (TPT). Error bars represent standard deviation over 6 replicates $(* p<0.05)$.

for TBT concentrations exceeding $94 \mathrm{ng} \mathrm{Sn/L}$. As the growth effect was not very intense in the concentration range tested, no reliable EC $x$ value could be calculated. Damaged shells were observed at all TPT concentrations tested (but not in controls), suggesting that TPT also had an impact on shell solidity (Figure 3B). Damage frequency was between $50 \%$ and $70 \%$, reglardless of exposure concentration. No significant effect on growth was found with TPT (Figure 2B).

\section{Egg-laying behavior}

The time-course of effect was different in snails exposed to TBT concentrations of $94 \mathrm{ng} \mathrm{Sn/L} \mathrm{or} \mathrm{less:} \mathrm{egg-laying} \mathrm{occurred}$ regularly but at a slower rate than in controls. For snails exposed to $197 \mathrm{ng} \mathrm{Sn} / \mathrm{L}$ and $473 \mathrm{ng} \mathrm{Sn} / \mathrm{L}$, egg-laying ceased after $1 \mathrm{wk}$ of exposure. The cumulated number of clutches produced per individual over $21 \mathrm{~d}$ decreased in all snails exposed to TBT compared with the water controls, from $-24 \%$ at $19 \mathrm{ng} \mathrm{Sn} / \mathrm{L}$ to $-96 \%$ at $473 \mathrm{ng} \mathrm{Sn} / \mathrm{L}$ (Figure 4A). A significant difference from solvent controls in the number of clutches produced $(p<0.05$, Dunnett's post hoc test) was detected at $94 \mathrm{ng} \mathrm{Sn/L}$. Exposure to the 2 highest TBT concentrations resulted in a severe reduction in egg-laying activity $(p<0.001$, Dunnett's post hoc test). The corresponding median effective concentration (EC50) at $21 \mathrm{~d}$ was estimated to be $118.3 \mathrm{ng} \mathrm{Sn} / \mathrm{L}$ (CI: 99.7$171.9 \mathrm{ng} \mathrm{Sn} / \mathrm{L})$.
In the TPT test, the time-course of effect was similar in snails exposed to all concentrations tested; snails regularly laid eggs, but the egg-laying rate was lower than in controls. Egg-laying activity was significantly lower in solvent controls $(p<0.05$, Wilcoxon rank sum test) than in water controls (Figure 4B). Solvent control was thus used as a reference for statistical tests for both TPT and TBT. Exposure to $265 \mathrm{ng} \mathrm{Sn} / \mathrm{L}$ and $590 \mathrm{ng} \mathrm{Sn} / \mathrm{L}$ caused a significant decrease $(p<0.01$ and $p<0.001$, respectively, Dunnett's post hoc test) in the cumulated number of clutches produced $(-38 \%$ and $-81 \%$ of the solvent control value, respectively). Based on these results, the estimated EC50 21-d value was $264.1 \mathrm{ng} \mathrm{Sn} / \mathrm{L}$ (CI: 258.5-280.5 ng Sn/L).

\section{Fecundity}

The effect patterns and estimated no-observed-effect concentration (NOEC) and lowest-observed-effect concentration (LOEC) values of TBT and TPT for fecundity were similar to the patterns observed for egg-laying behavior: the LOEC values were $94 \mathrm{ng} \mathrm{Sn/L}$ and $264 \mathrm{ng} \mathrm{Sn/L}(p<0.01$ and $p<0.001$, respectively, Dunnett's post hoc test) for TBT and TPT, respectively.

Compared with water controls, a nonsignificant reduction in fecundity was already observed at the 2 lowest TBT concentrations and was particularly severe at the 2 highest tested concentrations (from $-32 \%$ at $19 \mathrm{ng} \mathrm{Sn} / \mathrm{L}$ to $-97 \%$ at $473 \mathrm{ng} \mathrm{Sn} / \mathrm{L}$,

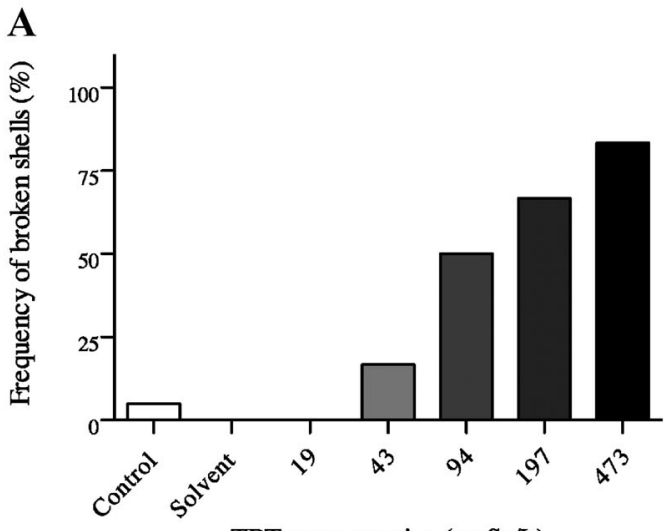

TBT concentration (ng $\mathrm{Sn} / \mathrm{L}$ )

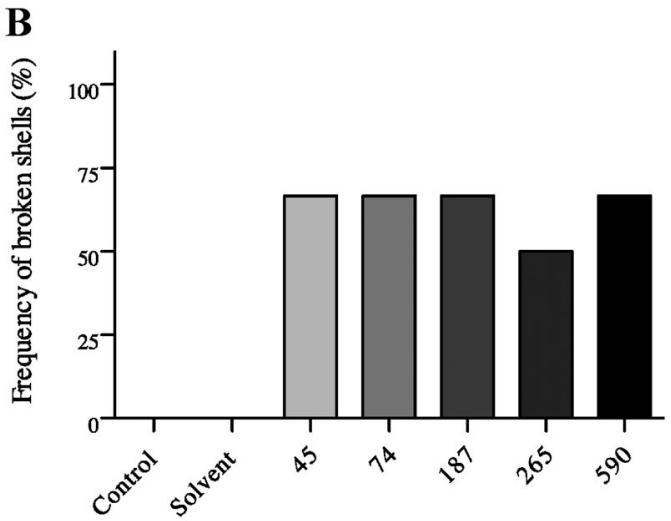

TPT concentration (ng Sn/L)

Figure 3. Frequency of broken shells observed over 6 replicates after a 21-d exposure to (A) tributyltin (TBT) or (B) triphenyltin (TPT). 
A

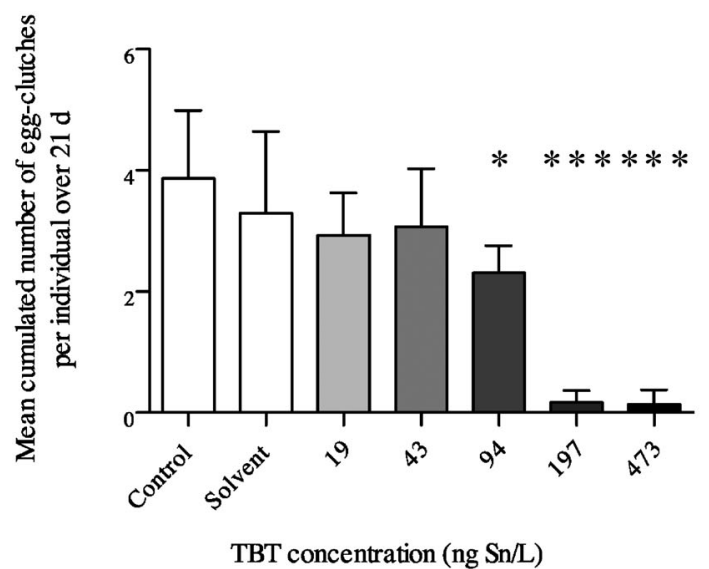

B

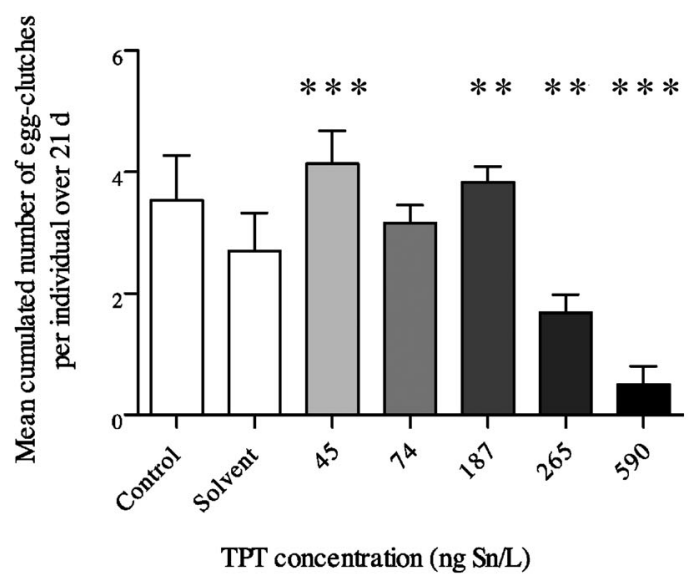

Figure 4. Mean cumulated number of egg-clutches laid per individual after a 21-d exposure to (A) tributyltin (TBT) or (B) triphenyltin (TPT). Error bars represent standard deviation over 6 replicates $\left({ }^{*} p<0.05 ;{ }^{* *} p<0.01 ;{ }^{* * *} p<0.001\right)$.

as shown in Figure 5A). The corresponding EC50 21-d value was $106.2 \mathrm{ng} \mathrm{Sn} / \mathrm{L}$ (CI: 84.4-125.6 ng Sn/L), which was not significantly different from the EC50 at $21 \mathrm{~d}$ found using oviposition as an endpoint.

A significant solvent effect on fecundity was again observed in the TPT test ( $p<0.01$, Wilcoxon rank sum test). Fecundity of the snails exposed to the 2 highest TPT concentrations (265 ng $\mathrm{Sn} / \mathrm{L}$ and $590 \mathrm{ng} \mathrm{Sn} / \mathrm{L})$ was significantly reduced $(-36 \%$ and $-85 \%$ of the solvent control value, respectively), as shown in Figure 5B. The corresponding EC50 21-d value was $263.9 \mathrm{ng}$ $\mathrm{Sn} / \mathrm{L}$ (CI: 253.8-280.5 ng Sn/L), which was similar to the EC50 at $21 \mathrm{~d}$ found for oviposition.

\section{Egg-abnormalities}

Frequency of abnormal eggs per clutch increased over the test duration. After $21 \mathrm{~d}$, it was significantly higher in snails exposed to TBT than in controls even at the lowest tested concentration of $19 \mathrm{ng} \mathrm{Sn} / \mathrm{L}(p<0.05$, Dunnett's post hoc test). The effects of TBT on the frequency of unfertilized eggs, eggs with atrophied albumen, and single-embryo were not significant. Frequency of polyembryony was the most interesting endpoint, representing $65 \%$ to $100 \%$ of observed abnormalities in the lowest and highest tested concentrations, respectively. It increased from $+80 \%$ at $19 \mathrm{ng} \mathrm{Sn} / \mathrm{L}$ to $+177 \%$ at $473 \mathrm{ng} \mathrm{Sn} / \mathrm{L}$ compared with control (Figure 6). This increase was significant for all concentrations tested ( $p<0.05$, Dunnett's post hoc test). The corresponding EC50 at $21 \mathrm{~d}$ was $23.7 \mathrm{ng} \mathrm{Sn} / \mathrm{L}$ (CI: 2.2-189.4 ng $\mathrm{Sn} / \mathrm{L}$ ). All eggs produced by parents exposed to $473 \mathrm{ng} \mathrm{Sn} / \mathrm{L}$ exhibited polyembryony. In contrast, TPT induced no significant effects on the viability of eggs produced by exposed adults at the tested concentration range.

\section{DISCUSSION}

\section{Chronic effects of organotins in L. stagnalis}

The TBT metabolite concentrations were very low (i.e., below the quantification limit), which suggests that degradation might not be the most significant process contributing to the decrease in TBT concentration in water. Losses were probably mostly due to adsorption in mucus, for example. Indeed, high TBT concentrations - 3- to 5-fold higher concentrations than the measured peak concentration in water-were found in mucus sampled after $21 \mathrm{~d}$. The TBT content in mucus most likely resulted from direct adsorption from water after the mucus was

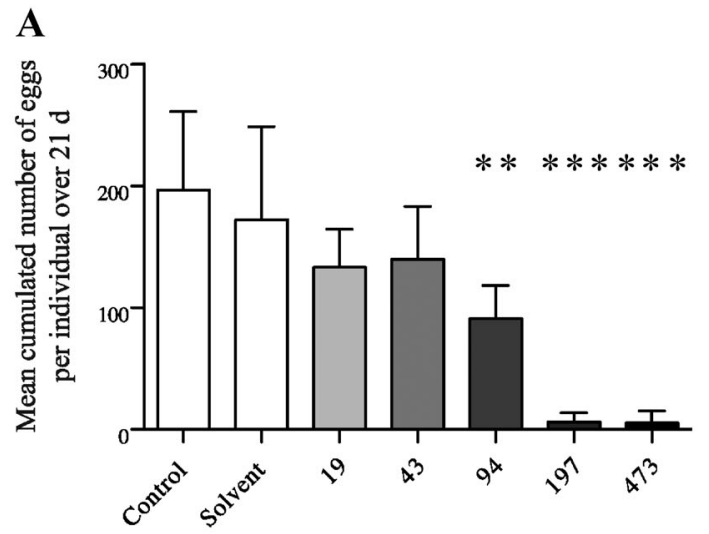

TBT concentration (ng $\mathrm{Sn} / \mathrm{L}$ )

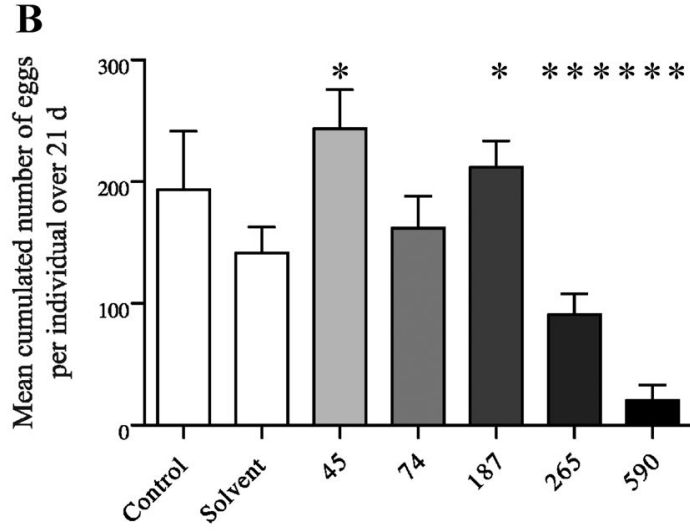

TPT concentration (ng Sn/L)

Figure 5. Mean cumulated number of eggs laid per individual after a 21-d exposure to (A) tributyltin (TBT) or (B) triphenyltin (TPT). Error bars represent standard deviation over 6 replicates $\left({ }^{*} p<0.05\right.$; $^{* *} p<0.01$; $^{* * *} p<0.001$ ). 


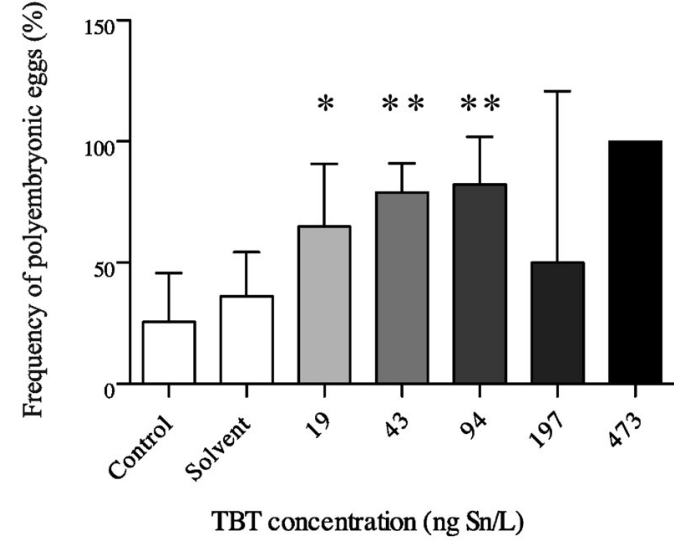

Figure 6. Frequency of the polyembryonic eggs (among the total number of abnormal eggs) found during a 21-d exposure to tributyltin (TBT). Error bars represent standard deviation over all abnormal eggs produced $\left({ }^{*} p<0.05 ;^{* *} p<0.01 ;^{* * *} p<0.001\right)$

released and possibly, to a lesser extent, from elimination of TBT by snails via mucus. This adsorption might partly explain why only $62.5 \%$ of the targeted nominal concentrations were found in the water samples. This highlights the need to wipe mucus off test beakers between water renewals to limit adsorption of TBT on the test chamber walls, which reduces its availability to the snails.

Exposure of L. stagnalis for $21 \mathrm{~d}$ to TPT in the concentration range of $45 \mathrm{ng} \mathrm{Sn} / \mathrm{L}$ to $590 \mathrm{ng} \mathrm{Sn} / \mathrm{L}$ induced mortality at the highest tested concentration (LC50 at $21 \mathrm{~d}, 436.1 \mathrm{ng} \mathrm{Sn} / \mathrm{L}$ ), and a variety of sublethal effects at lower concentrations, that is, decrease in shell solidity at all tested concentrations, decrease in egg-laying activity and fecundity, endpoints that led to an identical EC50 at 21-d value of $264 \mathrm{ng} \mathrm{Sn/L.} \mathrm{Egg} \mathrm{quality} \mathrm{at} \mathrm{the}$ concentration range tested was not affected by TPT.

A 21-d exposure of L. stagnalis to TBT in the range of $19 \mathrm{ng}$ $\mathrm{Sn} / \mathrm{L}$ to $473 \mathrm{ng} \mathrm{Sn} / \mathrm{L}$ did not result in significant mortality in the present study. Alternatively, Segner et al. [24] showed that adult survival was significantly reduced by TBT exposure, with an LC50 at $21 \mathrm{~d}$ of $290 \mathrm{ng} \mathrm{Sn/L} \mathrm{(nominal} \mathrm{concentration),} \mathrm{which} \mathrm{is}$ in contrast to both the present results and longer term studies from other authors. Indeed, no significant mortality was observed after $49 \mathrm{~d}$ and $84 \mathrm{~d}$ of exposure to $100 \mathrm{ng} \mathrm{Sn} / \mathrm{L}$ (nominal concentration [21]), as well as after $56 \mathrm{~d}$ of exposure to the concentration range of $7 \mathrm{ng} \mathrm{Sn} / \mathrm{L}$ to $181 \mathrm{ng} \mathrm{Sn} / \mathrm{L}$ (unpublished data from a round-robin test). At this concentration range, significant mortality was only observed in a 170-d study in which snails were exposed to $410 \mathrm{ng} \mathrm{Sn/L} \mathrm{[19].}$

Exposure to TBT induced a decrease in growth at concentrations exceeding $94 \mathrm{ng} \mathrm{Sn} / \mathrm{L}$. It also induced a decrease in shell solidity in snails exposed to concentrations exceeding $43 \mathrm{ng} \mathrm{Sn} / \mathrm{L}$, which was also observed by Segner et al. [24] in 21-d tests for nominal concentrations exceeding $94 \mathrm{ng} \mathrm{Sn/L.} \mathrm{Expo-}$ sure to TBT also induced a significant decrease in the egg-laying activity and fecundity of snails exposed to concentrations exceeding $45 \mathrm{ng} \mathrm{Sn} / \mathrm{L}$. This is consistent with previous results from Czech et al. [21], who observed a significant decrease in egg-laying at $100 \mathrm{ng} \mathrm{Sn/L} \mathrm{(nominal} \mathrm{concentration)} \mathrm{in} \mathrm{a} \mathrm{49-d}$ experiment. Overall, these data confirm the possible occurrence of reproductive effects in L. stagnalis exposed to TBT at environmentally relevant concentrations. Results obtained in our partial-life-cycle tests are in accordance with results obtained in other partial-life-cycle tests [21,24] but differ from results obtained in the 170-d full-life-cycle test published by Leung et al. [19], in which animals were exposed from embryonic stage to adulthood. In the study of Leung et al., adult fecundity was significantly modified at $41 \mathrm{ng} \mathrm{Sn} / \mathrm{L}$ (NOEC), which was also the case in the present study (NOEC, $43 \mathrm{ng} \mathrm{Sn/L}$ ). However, the effect pattern was quite different ( $\mathrm{S}$-shape dose-response curve in the present study vs inverted U-shape in the study of Leung et al. [19], with an increase in fecundity at $41 \mathrm{ng} \mathrm{Sn} / \mathrm{L}$ compared with controls). The magnitude of effects at $410 \mathrm{ng} \mathrm{Sn} / \mathrm{L}$ was also different. Indeed, the fecundity was reduced by a factor of 10 compared with control in the study of Leung et al. [19], whereas it was reduced by a factor 100 in the present study. These results suggest that the test design might greatly influence the biological responses of L. stagnalis. Further studies are needed to assess the influence of test duration on the endpoint values in partial lifecycle tests and to compare the sensitivity of partial versus full lifecycle tests with L. stagnalis.

Egg quality was altered by TBT, which was best evidenced through the frequency of polyembryonic eggs in clutches from exposed parents. The increase in polyembryony frequency was already significant at concentrations that were lower than those affecting egg production by adults. This finding indicates that polyembryony is more sensitive to TBT than the other reproductive endpoints tested (i.e., oviposition and fecundity, which are the common endpoints in reprotoxicity tests with snails), thus confirming previous findings with acetone [41]. Test endpoints/durations/protocols vary greatly among published studies on the effects of TBT in L. stagnalis, leading to a large variability in published NOEC values for some endpoints. This variability is also due to the lack of data on actual exposure concentrations in most published papers, which hampers a sound comparison of the published results. In this respect, the forthcoming standardization of reproductive toxicity test protocols with $L$. stagnalis will help in deriving more reliable conclusions on the toxicity of TBT, TPT, and other types of chemicals.

\section{Comparison of the responses of $L$. stagnalis to TBT versus TPT}

Differences in the sensitivity of L. stagnalis to similar concentration ranges of TBT and TPT were observed for most of the endpoints studied. The TBT concentrations tested (up to $473 \mathrm{ng} \mathrm{Sn/L)} \mathrm{had} \mathrm{no} \mathrm{significant} \mathrm{effect} \mathrm{on} \mathrm{survival,} \mathrm{whereas}$ $100 \%$ mortality was observed at the highest tested TPT concentration $(590 \mathrm{ng} \mathrm{Sn} / \mathrm{L})$, which suggests a higher toxicity of TPT than TBT to L. stagnalis. Results from a pretest with TBT confirmed that TBT has no effect on survival at $590 \mathrm{ng} \mathrm{Sn} / \mathrm{L}$. (The NOEC in this pretest was $627 \mathrm{ng} \mathrm{Sn/L}$, while the LOEC was $6270 \mathrm{ng} \mathrm{Sn/L}$, with $100 \%$ mortality occurring at the end of the test; data not shown.) A significant effect on snail growth was found with TBT, while no effect occurred due to TPT exposure. Because both TBT and TPT led to shell injuries, shell size might not be the most reliable growth indicator when assessing the effects of organotins on L. stagnalis. Indeed, decreased shell size due to an injury can be wrongly interpreted as an effect on growth. To avoid such misinterpretation, we recommend not using length data from individuals with broken shells for the statistical analysis of growth effects. Discarding such individuals from the analysis might lead to loss of a number of data and thus to a reduced statistical power when effects on growth are tested (e.g., in the present study, $100 \%$ of snails were injured at the highest TBT concentration). Growth effects should rather be assessed through measurement of the soft body dry weight to avoid misinterpretation and maintain a sufficient statistical power. It is likely that the decrease in shell solidity was due to decalcification, which has already been observed for TBT in $L$. 
stagnalis [24] and other mollusks (e.g., oysters [49]). Similarly, trialkylated tin compounds have been shown to interfere with calcification processes in mammals [49], which might also apply to L. stagnalis exposed to TPT.

Both compounds significantly reduced egg-laying and fecundity, but effective concentrations were lower for TBT than for TPT, as reflected by the EC50 21-d values for reproductive endpoints. The EC50s at $21 \mathrm{~d}$ based on fecundity data were equivalent to values obtained from oviposition data for TBT (EC50 21-d values of $106 \mathrm{ng} \mathrm{Sn/L} \mathrm{and} 118 \mathrm{ng} \mathrm{Sn/L}$, respectively; no significant difference as assessed through the overlapping of $95 \%$ confidence intervals) and for TPT (with a similar EC50 21-d value of $264 \mathrm{ng} \mathrm{Sn/L}$ and no overlapping of confidence intervals). These results suggest that both reproductive endpoints have a similar sensitivity to TPT and TBT in this particular experimental setup, although oviposition and fecundity are known to be under the control of 2 different hormonal pathways in L. stagnalis [32]. Exposure to TPT did not affect egg quality, whereas polyembryony often occurred in eggs produced by TBT-exposed snails. Polyembryony thus exhibited different responses to TBT and TPT and was the most sensitive endpoint in the TBT test. The use of acetone as the carrier solvent did not significantly influence snail reproduction or egg quality in the TBT test but did significantly hamper all reproductive performances in the TPT test. Previous in-house studies showed that reproductive effects due to acetone occur from time to time in our experimental conditions. The reasons remain unclear; this may be a result of, for example, differences in solvent purity or snail sensitivity from one experiment to another. This highlights the need for additional studies devoted to the assessment of solvent effects in juveniles and adults of L. stagnalis to complement the recently published results on solvent effects in embryos [43].

Reasons for differences in sensitivity of L. stagnalis to TBT versus TPT remain to be elucidated. Differences in molecular structure of these organotins might be a relevant explanation. Indeed, it is assumed that the toxicity of organotins is more influenced by the alkyl substitutes than by the anionic substitutes [6]. A recent study in Mytilus edulis confirmed that alkylation of organotins influences their toxicity to mollusks [50]. Therefore, differences in the responses of L. stagnalis to TPT versus TBT are likely to be related to differences in their alkylation. However, it is not known how such differences in molecular structure might lead to different modes of action of these compounds in L. stagnalis. Previous studies highlighted the possible endocrine effects of TBT and TPT in gastropods [51-55]. Hormonal pathways involved in the response of various gastropods to TBT were investigated, focusing on the mechanisms of imposex induction in gonochoric marine species [51,54,56-58]. These studies highlighted the fact that imposex is related to an alteration in steroid homeostasis, mediated by inhibition of enzymes such as cytochrome-P450 aromatase or acyltransferase that are involved in biosynthetic steroid pathways $[53,57,59]$. Other in vivo and in vitro studies showed that TBT and TPT are potent activators of nuclear receptors such as the retinoid X-receptors, leading to transcription of genes involved in steroid homeostasis [52,60-63]. Other studies highlighted the effects of TBT and TPT on different components of the microsomal monooxygenase system of the bivalves Mytilus galloprovincialis and Ruditapes decussata and of the gastropod Thais haemastoma [64]. Finally, Lyssimachou et al. [15] showed that TPT was able to alter lipid metabolism in females of the ramshorn snail Marisa cornuarietis. However, it is not known to what extent these findings can be extrapolated to hermaphroditic species such as L. stagnalis. In the present study, reproductive effects of TPT occurred at quite high concentrations (i.e., the LC50 at $21 \mathrm{~d}$ was only 2 -fold higher than the reproductive EC50 at $21 \mathrm{~d}$ ). Values for EC50 at $21 \mathrm{~d}$ were similar when estimated using fecundity or egg-laying data, indicating no relationship between the hormonal pathways involved in the control of these processes and the biological response. Furthermore, no significant increase in the frequency of abnormalities occurred in the offspring of exposed snails. Therefore, results of the apical reproduction test suggest that the reproductive impacts observed are probably linked to the toxicity of TPT to the snails rather than being a consequence of endocrine disruption. Alternatively, TBT concentrations that induced reproductive effects in $L$. stagnalis were much lower than the lethal concentrations reported in other studies conducted with this species [19,24], and occurred at environmentally relevant concentrations. In addition, the frequency of polyembryony in the offspring increased in exposed snails. These results suggest that TBT might act as an endocrine disruptor in L. stagnalis as well. Even if apical endpoints might bring clues to possible modes of action of TBT and TPT in L. stagnalis, studies should be implemented to determine to what extent and for which compounds the observed deleterious effects of organotins are actually due to endocrine disruption $[31,32]$.

\section{Comparison of responses of the hermaphroditic snail and gonochoric species}

Existing data, including the present results, have shown that TPT and TBT have different acute and chronic effects in various mollusk species. For instance, exposure of the parthenogenetic snail Potamopyrgus antipodarum to TBT and TPT in sediment biotests led to a significant reduction in reproductive output at environmentally relevant concentrations [8,65]. Effect concentrations were lower and the intensities of effects on reproduction were higher in mud snails exposed to TPT compared with those exposed to TBT. In contrast, acute toxicity occurred in snails exposed to TBT but not in those exposed to TPT. Based on these results, the effects of TPT and TBT in $P$. antipodarum are opposite to the effects we found in L. stagnalis. In another study, it was shown that females of the rock shell T. clavigera had a similar sensitivity to TBT and TPT (via direct injection in soft tissues), while males were more sensitive to TPT than to TBT [17]. Interestingly, it appears that 3 prosobranch snails with different habitats (freshwater, brackish water, and marine water) and different reproductive strategies (parthenogenesis, hermaphrodism, and gonochorism) were all responsive to organotin compounds, but their sensitivities were species- and sexdependent, as reviewed by Ketata et al. [66]. Additional studies are required to provide explanations for differences in responsiveness and sensitivity to TBT and TPT in and between species.

Acknowledgment-The present study was financially supported by Belgium funds under a FNRS-F.R.I.A. grant (Fonds pour la Formation à la Recherche dans l'Industrie et dans l'Agriculture), by the European Union under the 7th Framework Programme project Mechanistic Effect Model for Ecological Risk Assessment of Chemicals [CREAM], contract number PITN-GA-2009238148), and by French funds from the Agency for Food, Environmental and Occupational Health Safety under the "Programme Environnement-SantéTravail de l'ANSES avec le soutient de l'ITMO cancer dans le cadre du Plan Cancer 2009-2013, contract MODENDO, number EST/2011/1/153." The authors thank the Experimental Unit of Aquatic Ecology and Ecotoxicology at the French National Institue for Agricultural Research for providing snails and experimental facilities and its technical staff for their support during toxicity tests. We also thank L. Weltje for his advice, which contributed to improve the present study. Finally, we thank the anonymous reviewers who supported the publication of the present study and contributed to its improvement. 


\section{REFERENCES}

1. Hobler C, Andrade AJM, Grande SW, Gericke C, Talsness CE, Appel KE, Chahoud I, Grote K. 2010. Sex-dependent aromatase activity in rat offspring after pre- and postnatal exposure to triphenyltin chloride. Toxicology 276:198-205.

2. International Maritime Organization. 2005. International Convention on the Control of Harmful Anti-fouling Systems on Ships adopted on the 05/10/2001. IMO [cited 15 October 2012]. Available from: http://www. imo.org. London, UK

3. International Programme on Chemical Safety. 1990. Tributyltin compounds. Environmental Health Criteria 116. World Health Organisation, Geneva, Switzerland.

4. De Oliveira CR, Dos Santos D, Dos Santos Madureira LA, De Marchi MRR. 2010. Speciation of butyltin derivatives in surface sediments of three southern Brazilian harbors. J Hazard Mater 181:851-856.

5. Bigatti G, Primost MA, Cledón M, Averbuj A, Theobald N, Gerwinski W, Arntz W, Morriconi E, Penchaszadeh PE. 2009. Biomonitoring of TBT contamination and imposex incidence along $4700 \mathrm{~km}$ of Argentinean shoreline (SW Atlantic: From 38S to 54S). Mar Pollut Bull 58:695-701.

6. Antizar-Ladislao B. 2008. Environmental levels, toxicity and human exposure to tributyltin (TBT)-contaminated marine environment. A review. Environ Int 34:292-308.

7. Forsyth DS, Casey V. 2003. Butyltin compounds in retail mollusc products. Food Add Contam 20:445-452.

8. Duft M, Schulte-Oehlmann U, Tillmann M, Markert B, Oehlmann J. 2003. Toxicity of triphenyltin and tributyltin to the freshwater mud snail Potamopyrgus antipodarum in a new sediment biotest. Environ Toxicol Chem 22:145-152.

9. Strand J, Jacobsen JA. 2005. Accumulation and trophic transfer of organotins in a marine food web from the Danish coastal waters. Sci Total Environ 350:72-85.

10. Harino H, Fukushima M, Kawai S. 2000. Accumulation of butyltin and phenyltin compounds in various fish species. Arch Environ Contam Toxicol 39:13-19.

11. Alzieu C. 1998. Tributyltin: Case study of a chronic contaminent in the coastal environment. Ocean Coast Manag 40:23-36.

12. Gibbs PE, Pascoe PL, Burt GR. 1988. Sex change in the female dogwhelk, Nucella lapillus, induced by tributyltin from antifouling paints. $J$ Mar Biol Assoc UK 68:715-731.

13. Horiguchi T, Lee J-H, Park J-C, Cho H-S, Shiraishi H, Morita M. 2012. Specific accumulation of organotin compounds in tissues of the rock shell, Thais clavigera. Mar Environ Res 76:56-62.

14. Bauer B, Fioroni P, Schulte-Oehlmann U, Oehlmann J, Kalbfus W. 1997. The use of Littorina littorea for tributyltin (TBT) effect monitoring-Results from the German TBT survey 1994/1995 and laboratory experiments. Environ Pollut 96:299-309.

15. Lyssimachou A, Navarro JC, Bachmann J, Porte C. 2009. Triphenyltin alters lipid homeostasis in females of the ramshorn snail Marisa cornuarietis. Environ Pollut 157:1714-1720.

16. Schulte-Oehlmann U, Tillmann M, Markert B, Oehlmann J. 2000. Effects of endocrine disruptors on prosobranch snails (Mollusca: Gastropoda) in the laboratory. Part II: Triphenyltin as a xeno-androgen. Ecotoxicology 9:399-412.

17. Horiguchi T, Shiraishi H, Shimizu M, Morita M. 1997. Effects of triphenyltin chloride and five other organotin compounds on the development of imposex in the rock shell, Thais clavigera. Environ Pollut 95:85-91.

18. Leung KMY, Morley NJ, Grist EPM, Morritt D, Crane M. 2004. Chronic toxicity of tributyltin on development and reproduction of the hermaphroditic snail Physa fontinalis: Influence of population density. Mar Environ Res 58:157-162.

19. Leung KMY, Grist EPM, Morley NJ, Morritt D, Crane M. 2007. Chronic toxicity of tributyltin to development and reproduction of the European freshwater snail Lymnaea stagnalis (L.). Chemosphere 66:1358-1366.

20. Lagadic L, Coutellec M-A, Caquet T. 2007. Endocrine disruption in aquatic pulmonate molluscs: Few evidences, many challenges. Ecotoxicology 16:45-59.

21. Czech P, Weber K, Dietrich DR. 2001. Effects of endocrine modulating substances on reproduction in the hermaphroditic snail Lymnaea stagnalis L. Aquat Toxicol 53:103-114.

22. Schulte-Oehlmann U, Bettin C, Fioroni P, Oehlmann J, Stroben E. 1995. Marisa cornuarietis (Gastropoda, prosobranchia): A potential TBT bioindicator for freshwater environments. Ecotoxicology 4:372-384

23. Janer G, Lyssimachou A, Bachmann J, Oehlmann J, Schulte-Oehlmann U, Porte C. 2006. Sexual dimorphism in esterified steroid levels in the gastropod Marisa cornuarietis: The effect of xenoandrogenic compounds. Steroids 71:435-444.
24. Segner H, Caroll K, Fenske M, Janssen CR, Maack G, Pascoe D, Schäfers C, Vandenbergh GF, Watts M, Wenzel A. 2003. Identification of endocrine-disrupting effects in aquatic vertebrates and invertebrates: Report from the European IDEA project. Ecotoxicol Environ Saf 54:302-314.

25. Ceulemans M, Slaets S, Adams F. 1998. Speciation of organotin in environmental sediment samples. Talanta 46:395-405.

26. Jadhav S, Bhosale D, Bhosle N. 2011. Baseline of organotin pollution in fishes, clams, shrimps, squids and crabs collected from the west coast of India. Mar Pollut Bull 62:2213-2219.

27. Horiguchi T, Shiraishi H, Shimizu M, Morita M. 1994. Imposex and organotin compounds in Thais clavigera and T. bronni in Japan. J Mar Biol Assoc UK 74:651-669.

28. Lyssimachou A, Ramon M, Porte C. 2009. Comparative study on the metabolism of the androgen precursor androstenedione in two gastropod species: In vitro alterations by TBT and TPT. Comp Biochem Physiol C 149:409-413.

29. Jarne P, David P, Pointier J, Koene J. 2010. Basommatophoran gastropods. In Córdoba-Aguilar A, Leonard JL, eds, The Evolution of Primary Sexual Characters in Animals. Oxford University Press Oxford, UK, pp. 173-196.

30. Coutellec M-A, Lagadic L. 2006. Effects of self-fertilization, environmental stress and exposure to xenobiotics on fitness-related traits of the freshwater snail Lymnaea stagnalis. Ecotoxicology 15:199-213.

31. Matthiessen P. 2008. An assessment of endocrine disruption in mollusks and the potential for developing internationally standardized mollusk life cycle test guidelines. Integr Environ Assess Manag 4:274-284.

32. Koene J. 2010. Neuro-endocrine control of reproduction in hermaphroditic freshwater snails: Mechanisms and evolution. Front Behav Neurosci 4:167-167.

33. Organization for Economic Cooperation and Development. 1999. Report from the OECD consultation on testing in Fish, 28-29 October, London, UK. Paris, France.

34. Geraerts WPM. 1976. The control of ovulation in the hermaphroditic freshwater snail Lymnaea stagnalis by the neurohormone of the caudodorsal cells. Gen Comp Endocrinol 28:350-357.

35. Ducrot V, Teixeira-Alves M, Lopes C, Delignette-Muller M-L, Charles S, Lagadic L. 2010. Development of partial life-cycle experiments to assess the effects of endocrine disruptors on the freshwater gastropod Lymnaea stagnalis: A case-study with vinclozolin. Ecotoxicology 19:1312-1321.

36. Organization for Economic Cooperation and Development. 2000. Guidance document on aquatic toxicity testing of difficult substances and mixtures. OECD Series on Testing and Assessment 23. ENV/JM/ MONO (2000) 6. Paris, France.

37. Oehlmann J, Fioroni P, Stroben E, Markert B. 1996. Tributyltin (TBT) effects on Ocinebrina aciculata (Gastropoda: Muricidae): Imposex development, sterilization, sex change and population decline. Sci Total Environ 188:205-223.

38. Giusti A, Ducrot V, Joaquim-Justo C, Laurent L, Thomé J-P. 2010. Effects of androgenic and anti-androgenic substances on the freshwater gastropod Lymnaea stagnalis. Abstracts, SETAC Europe 20th Annual Meeting: Science and Technology for Environmental Protection, Seville, Spain, 23-27 May, 2010, p 146.

39. Barsi A, Ducrot V, Jager T, Lagadic L. 2011. Mechanistic modelling of effects of endocrine disruptors in populations of the pond snail Lymnaea stagnalis. Krakow.

40. Zimmer E, Jager T, Ducrot V, Lagadic L, Kooijman SALM. 2012. Juvenile food limitation in standardized tests: A warning to ecotoxicologists. Ecotoxicology 21:2195-2204.

41. Bluzat R, Jonot O, Lespinasse G, Seuge J. 1979. Chronic toxicity of acetone in the fresh water snail Lymnea stagnalis. Toxicology 14:179-190.

42. Lanzer. 1999. Toxicity of nonylphenol during embryo growth in Lymnaea stagnalis GSF report. L. Institut für Ökologische Chemie, Neuherberg, Munich, Germany.

43. Bandow C, Weltje L. 2012. Development of an embryo toxicity test with the pond snail Lymnaea stagnalis using the model substance tributyltin and common solvents. Sci Total Environ 435-436:90-95.

44. British Standards Institution. 2004. Water Quality: Determination of Selected Organotin Compounds-Gas Chromatographic Method. London, UK, p 31.

45. Belgers JDM, Aalderink GH, Arts GHP, Brock TCM. 2011. Can timeweighted average concentrations be used to assess the risks of metsulfuron-methyl to Myriophyllum spicatum under different timevariable exposure regimes? Chemosphere 85:1017-1025.

46. Organization for Economic Cooperation and Development. 2006 Current Approaches in the Statistical Analysis of Ecotoxicity Data: A Guidance to Application. Paris, France. 
47. Duggleby RG. 1981. A nonlinear regression program for small computers. Anal Biochem 110:9-18.

48. Vindimian E. 2001. The biological monitoring of toxic impacts on the environment. Cell Mol Biol 47:1309-1318.

49. Alzieu C, Héral M, Thibaud Y, Dardignac M-J, Feuillet M. 1982. Influence des peintures antisalissures à base d'organostatiques sur la calcification de l'huitre Crassostrea gigas. Rev Trav Inst Peches Mar 45:101-116.

50. Nesci S, Ventrella V, Trombetti F, Pirini M, Borgatti AR, Pagliarani A. 2011. Tributyltin (TBT) and dibutyltin (DBT) differently inhibit the mitochondrial Mg-ATPase activity in mussel digestive gland. Toxicol In Vitro 25:117-124.

51. Gooding MP, Wilson VS, Folmar LC, Marcovich DT, LeBlanc GA. 2003. The biocide tributyltin reduces the accumulation of testosterone as fatty acid esters in the mud snail (Ilyanassa obsoleta). Environ Health Perspect 111:426-430.

52. Castro LFC, Lima D, Machado A, Melo C, Hiromori Y, Nishikawa J, Nakanishi T, Reis-Henriques MA, Santos MM. 2007. Imposex induction is mediated through the retinoid $\mathrm{X}$ receptor signalling pathway in the neogastropod Nucella lapillus. Aquat Toxicol 85:57-66.

53. Spooner N, Gibbs PE, Bryan GW, Goad LJ. 1991. The effect of tributyltin upon steroid titres in the female dogwhelk, Nucella lapillus, and the development of imposex. Mar Environ Res 32:37-49.

54. Santos MM, Castro LFC, Vieira MN, Micael J, Morabito R, Massanisso P, Reis-Henriques MA. 2005. New insights into the mechanism of imposex induction in the dogwhelk Nucella lapillus. Comp Biochem Physiol C 141:101-109.

55. Bettin C, Oehlmann J, Stroben E. 1996. TBT-induced imposex in marine neogastropods is mediated by an increasing androgen level. Helgol Meeresunters 50:299-317.

56. Sternberg RM, LeBlanc GA. 2006. Kinetic characterization of the inhibition of acyl coenzyme A: Steroid acyltransferases by tributyltin in the eastern mud snail (Ilyanassa obsoleta). Aquat Toxicol 78:233-242.
57. Ronis MJJ, Mason AZ. 1996. The metabolism of testosterone by the periwinkle (Littorina littorea) in vitro and in vivo: Effects of tributyl tin. Mar Environ Res 42:161-166.

58. LeBlanc GA, Gooding MP, Sternberg RM. 2005. Testosterone-fatty acid esterification: A unique target for the endocrine toxicity of tributyltin to gastropods. Integr Comp Biol 45:81-87.

59. Sternberg RM, Gooding MP, Hotchkiss AK, LeBlanc GA. 2010. Environmental-endocrine control of reproductive maturation in gastropods: Implications for the mechanism of tributyltin-induced imposex in prosobranchs. Ecotoxicology 19:4-23.

60. Kanayama T, Kobayashi N, Mamiya S, Nakanishi T, Nishikawa J-I 2005. Organotin compounds promote adipocyte differentiation as agonists of the peroxisome proliferator-activated receptor $\gamma /$ retinoid $X$ receptor pathway. Mol Pharmacol 67:766-774.

61. Nishikawa J-I. 2006. Imposex in marine gastropods may be caused by binding of organotins to retinoid X receptor. Mar Biol 149:117-124.

62. Nakanishi T. 2008. Endocrine disruption induced by organotin compounds; organotins function as a powerful agonist for nuclear receptors rather than an aromatase inhibitor. J Toxicol Sci 33: 269-276.

63. Nishikawa J-I, Mamiya S, Kanayama T, Nishikawa T, Shiraishi F, Horiguchi T. 2004. Involvement of the retinoid X receptor in the development of imposex caused by organotins in gastropods. Environ Sci Technol 38:6271-6276.

64. Morcillo Y, Porte C. 1997. Interaction of tributyl- and triphenyltin with the microsomal monooxygenase system of molluses and fish from the Western Mediterranean. Aquat Toxicol 38:35-46.

65. Schulte-Oehlmann U. 1997. Fortpflanzungsstörungen bei Süßund Brackwasserschnecken-Einfluß der Umweltchemikalie Tributylzinn. Wissenschaft und Technik Verlag, Berlin, Germany.

66. Ketata I, Denier X, Hamza-Chaffai A, Minier C. 2008. Endocrine-related reproductive effects in molluscs. Comp Biochem Physiol C 147:261270. 